\title{
In search of 'home' for wellness: Mental health social workers' views on homelessness in mental health
}

\author{
Shoichi Isogai ${ }^{1}$
}

\begin{abstract}
INTRODUCTION: There is a lack of acknowledgement of the homelessness crisis for tāngata whaiora (all people who have lived experience of mental illness and/or are users of mental health services, including Māori) in Aotearoa/New Zealand. This article reports the findings from an exploratory study of how mental health social workers perceive the challenge of homelessness amongst tāngata whaiora in urban Auckland.
\end{abstract}

METHOD: This small exploratory qualitative study used semi-structured interviews with mental health social workers to discover their views about the issue of homelessness among tāngata whaiora in urban Auckland.

FINDINGS: The research illustrates that homelessness is prevalent among tāngata whaiora in urban Auckland, and the cyclical nature of this problem presents a serious obstacle for their recovery. This study also found that the lives of tāngata whaiora are affected by iterative homelessness. Participants were clear that tāngata whaiora do not choose to be homeless; rather individual, structural and community factors cause them to be homeless.

CONCLUSION: The policy and mental health practice implications of these findings are discussed.

KEYWORDS: homelessness; iterative homelessness; recovery; mental health social work

\section{Introduction}

For many people, home is a safe and secure place where they can be themselves without being judged. Having somewhere to call home is one of the fundamental aspects of recovery for all tāngata whaiora $\left(\mathrm{O}^{\prime}\right.$ Brien \& Leggatt-Cook, 2006), as home provides a place to manage their mental illness. However, homelessness is one of the serious challenges that tāngata whaiora frequently face in Aotearoa New Zealand (hereafter referred to as Aotearoa). Tāngata whaiora as used in this article refers to all people who have lived experience of mental illness and/or are users of mental health services. This Māori term is interpreted as people in search of wellness, illuminating the contemporary notion of the relationship between New Zealanders, mental health and mental health services $\left(\mathrm{O}^{\prime}\right.$ Brien \& Leggatt-Cook, 2006).

The present study explored the perspectives of mental health social workers about homelessness in tāngata whaiora in Auckland. Although there is a considerable body of research about the housing needs of tāngata whaiora in Aotearoa (Colwell, 2009; Elgin, 2010; Peace, Kell, Pere, Marshall, \& Ballantyne 2002), there is a lack of acknowledgement amongst the general public of urban Auckland about the homelessness crisis for people engaged in mental health services. Hence Auckland, the largest metropolitan city in Aotearoa, which also has a super-diverse population (Chen,
${ }^{1}$ This article is based on a thesis submitted for the MASW at Massey University
AOTEAROA

NEW ZEALAND SOCIAL WORK 28(3), 67-78.

CORRESPONDENCE TO Shoichi Isogai shomatters0202@gmail.com 
2015), is the best laboratory in which to study the issue of homelessness in the country.

While the issues emerging from this study are specific to Auckland, the findings are relevant for all New Zealanders, particularly for tāngata whenua whaiora as Māori are over-represented in both mental health admissions (Gawith \& Abrams, 2006) and in the population of homeless people in Aotearoa (Richards, 2009). Understanding the challenges of homelessness and its impact will allow social workers and service providers to provide sufficient and effective services to at-risk homeless tāngata whaiora, while at the same time creating a supportive system and network for tāngata whaiora, to choose and maintain housing for their recovery.

\section{Literature review}

Defining homelessness is problematic as there has long been debate over the conceptual framework and classification of homelessness, and there is no clear international consensus (Amore, Baker \& Howden-Chapman, 2011; Harris, 2015). Chamberlain and MacKenzie (1992) state that homelessness is a relative concept as it obtains meaning based on the housing conventions in a specific culture.

In Aotearoa New Zealand, various authors have attempted to define and classify homelessness in terms of who is included as homeless people (Amore et al. 2013; Leggatt-Cook, 2007a; Richards, 2009; Statistics New Zealand, 2014). Statistics New Zealand introduced the first official definition of homelessness in Aotearoa in 2009 based on the European Typology of Homelessness and Housing Exclusion (ETHOS) (see Amore et al., 2011). They refer to the homelessness situation in Aotearoa as "living situations where people with no other options to acquire safe and secure housing" (Statistics New Zealand, 2009, p.6). Statistics New Zealand describe living situations as including: those without shelter (people who live in no accommodation or temporary shelter); in temporary accommodation (people who live in a shelter overnight, or other 24hour non-private dwellings that are intended for a short-term stay); sharing accommodation with a household (people who live in someone else's private dwelling temporarily); or, living in uninhabitable housing (people who live in a dilapidated house) (Statistics New Zealand, 2009). The official definition of homelessness in Aotearoa was updated in 2014 with little modification (Statistics New Zealand, 2014). This new official definition of homelessness excludes the following statement from 2009, "those who remain institutionalised because accommodation in the community is not available are not defined as homeless" (Statistics New Zealand, 2009, pp. 7)

In 2013, Amore et al. (2013) reviewed the official definition of homelessness in Aotearoa, replacing the term with severe housing deprivation. The new term refers to people who live in severely inadequate housing, caused by a lack of access to minimally adequate housing ( $L A M A H)$. Amore et al. (2013) explained three fundamental dimensions of adequate housing, including, habitability, privacy and control and tenancy security. Using this definition, people (including tāngata whaiora) who remain in hospital or community-based residential care, are only counted as LAMAH if they complete the treatment in the hospital and have no minimally adequate housing to be discharged to (Amore et al., 2013).

The 2012/2013 New Zealand Health Survey highlighted that one in six adults, living in Aotearoa were diagnosed with major mental illness at some time in their lives (Mental Health Foundation of New Zealand, 2014). About $20 \%$ of the population in Aotearoa will experience a mental illness at any time; about $40 \%$ have had some form of mental illness, while $20.7 \%$ have had a mental illness in the past 12 months (Browne, Wells, \& Scotts, 2006).

A recent study showed that one in every 120 people in Aotearoa is either homeless or atrisk of severe housing deprivation (Amore, 
Viggers, Baker, \& Howden-Chapman, 2013). According to the Auckland City Mission's 2013 street count, about 68 people were rough sleepers, eight were at risk of being homeless and living in hostels, and 13 were in institutional care (Auckland City Mission as cited in Parliamentary Library, 2014). Notwithstanding the Auckland street count, there are few statistics available about homeless tāngata whaiora in Aotearoa. The only official research to measure the number of homeless tāngata whaiora was conducted by Peace et al. (2002). They estimated using national data that 8000 tāngata whaiora might be having housing difficulties, 2000 might be perceived as living in temporary or emergency accommodation or homeless and 8000 were at-risk of homelessness due to their living circumstances in 2001.

\section{Causes of homelessness for tāngata whaiora}

There is ongoing debate on the cause of homelessness within the literature. The argument lies on a continuum between an individualist approach (voluntary or individual failures lead to homelessness) on the one hand, and a structural approach (macro socio-economic factors cause people to be homeless) on the other (Leggatt-Cook, 2007a; Leggatt-Cook \& Chamberlain, 2015). Several scholars have explored individual and structural causes of homelessness among tāngata whaiora nationally and internationally (Kell \& Peace, 2002; MHCA, 2009).

Various scholars explain that it is a widely held view that some homeless people choose to be homeless where homelessness is a lifestyle choice or the result of individual failures due to lack of morale or laziness (Laurenson, \& Collins, 2006; Leggatt-Cook \& Chamberlain, 2015). Others indicate that having severe mental illness causes tāngata whaiora to become homeless as the illness prevents them from forming and maintaining stable relationships (Kell \& Peace, 2002; National Coalition for the Homeless, 2009). Nevertheless, Leggatt-Cook (2007a) argued that housing unavailability and unaffordability, caused by economic restructuring along with changes in welfare and housing policy, are major causes of homelessness. Additionally, discrimination and stigmatisation are causal factors of homelessness among tāngata whaiora as they are vulnerable to exploitation by the public (Peace et al., 2002).

There has been an emerging trend towards what is known as the 'both/and' view of the causes of homelessness (Christian, 2003; Leggatt-Cook \& Chamberlain, 2015). Several researchers have recognised that the causes of homelessness are overwhelmingly heterogeneous and occur via a complex combination of wide-ranging social and economic factors and personal life incidences and situations (Morrell-Bellai et al., 2000; Leggatt-Cook, 2007a). Thus, both individualist and structural approaches are sometimes presented as two sides of an equilateral relationship and represent major views of the causes of homelessness.

\section{Recovery and its relationship to 'home'}

The relationship between housing and recovery from mental illness has been illustrated in both international and Aotearoa New Zealand studies (Fieldhouse \& Onyett, 2012; MHCA, 2009; O’Brien \& Leggatt-Cook, 2006). Several scholars state that having a place to call home is integral to the recovery of tāngata whaiora as affordable, adequate and sustainable housing plays a central role in supporting their independent living in the community (MHCA, 2009; Peace et al., 2002).

Services in Aotearoa New Zealand have adapted a recovery-oriented approach to service delivery (Cheer, 2009). Recovery refers to, "living well in the community with natural supports. Recovery does not always mean people will return to full health or retrieve all their losses, but people can and do live well despite this" (Mental Health Commission, 2012, pp.11). It is a peoplecentred concept and a philosophy of human 
rights that emphasises the concepts of hope, self-determination and active citizenship participation in society (MHFNZ, 2008).

Recovery for tāngata whaiora has often been seen to be on a continuum between the points of recovery as a process on one hand and recovery as an outcome on the other (Ramon, Healy, \& Renouf, 2007). Piat, Sabetti and Couture (2009) explained that recovery is an active and on-going process of individual change allowing a person to live with mental illness in the community, rather than reaching to the completion of the illness. In contrast, others have claimed that recovery is an outcome as reaching a place they can call home is the result of recovery from mental illness (Bond et al., 2004). Currently, there is a growing recognition that a 'both/and' view is necessary for services that work with tāngata whaiora. Ramon et al. (2007) noted that recovery is a "complex and multifaceted concept, both a process and an outcome, the features of which include strength, self-agency, hope, interdependency, and systematic effort" (pp. 119).

\section{Methodology}

This small exploratory qualitative study used semi-structured interviews with three mental health social workers to discover their views about the issue of homelessness among tāngata whaiora in urban Auckland. All interviewees were qualified social workers who have worked with homeless tāngata whaiora extensively in the mental health service in one of the District Health Boards (DHBs) in Auckland. Full ethics approval was obtained from the Massey University Human Ethics Committee in 2012. Data were anonymised, then thematically analysed. Initial coding was developed based on the topic outlined in the semi-structural interview guide and from key themes in the interviews. Member checking and digital recording were used to ensure the participants' perspectives were appropriately reported.

The author acknowledges that the qualitative data can only present a narrow view of mental health social workers' understanding of homelessness among tāngata whaiora. Furthermore, due to limited resources and time, the small scale of this research and findings cannot be representative of all mental health social workers' perspectives on homelessness in urban Auckland. However, the purpose of qualitative research is to understand a challenge at a deeper level rather than to generalise, so this study is reported to develop mental health social workers' understanding of homelessness and mental illness in Aotearoa New Zealand. Interviewing social workers who work with homeless persons was a practical way of exploring the challenge while respecting the dignity of tāngata whaiora.

\section{Findings}

Four key themes emerged from the data. These were: understanding of the links between homelessness and home in mental health; the causes and consequences of homelessness for tāngata whaiora; understanding of the recovery concept and its relationship to home and policy and mental health practice implications.

\section{Understanding the link between homelessness and home in mental health}

Generally, all participants explained their understanding of homelessness in mental health in terms of its definition and the serious impact it has on the lives of tāngata whaiora. They described the homeless in this context as people who live in temporary or emergency accommodation or who have insecure and inappropriate accommodation and remain housed at continued risk of being rough sleepers:

Homelessness is people who do not have a stable place to live, like a transient. So, [there is] no place for them to live comfortably. (Steven)

With respect to perspectives on 'home' for tāngata whaiora, there was a mutual 
agreement amongst participants that tāngata whaiora have similar understanding of the concept of home as they are no different from any other members of the community. Further, the majority of participants explained that home was a place where tāngata whaiora know people, customs and/or culture and can be members of their community:

Somewhere that you want to return to, that you can return to, and that is somewhere where there is some sense of you having a place and position within a community. (Eric)

\section{The causes and consequences of homelessness for tāngata whaiora}

There appears to be a shared understanding among participants that homelessness and mental illness are indirectly related to each other as they are mutually reinforcing. For instance, Eric commented that symptoms increase the risk of homelessness for tāngata whaiora while homelessness exacerbates mental health issues for homeless people.

When exploring the cause of homelessness, all participants commented that homelessness is a result of choicelessness for tāngata whaiora. Two participants noted that it is one of the "myths of life" that people choose to be homeless, explaining that:

Becoming homeless is the least worst decision that they felt they could take at that particular point in their lives. (Eric)

Some professionals have made them homeless because they feel that their accommodations are unacceptable. (Kate)

Participants described the causes of homelessness among tāngata whaiora in terms of individual, structural and community factors. Participants considered that there were two types of individual causes of homelessness for tāngata whaiora: symptoms of mental illness and lack of organisational skills. Symptoms were the key feature of individual causes of homelessness for tāngata whaiora. Participants explained that when tāngata whaiora become unwell, their symptoms become obvious to family / whānau members or landlords. Their symptoms led these people to perceive them as a risk, which could then result in homelessness for the person who was unwell. Ultimately, because mental illness takes over the cognitive process of tāngata whaiora, they felt compelled to be homeless:

They [tāngata whaiora] may also seek to become homeless in a sense that they may have serious delusions, hallucinations about people seeking to endanger them; they may actually think that living an anonymous existence is a good way of responding to such situations. (Eric)

Lack of organisational skills, such as budgeting and cleaning, is another individual cause of homelessness for tāngata whaiora. Kate explained how tāngata whaiora become rough sleepers as they have no skills and confidence to live independently:

Somebody goes into institutions at a young age and they can become institutionalised and therefore, have no skills, ability or confidence to live on their own. (Kate)

On the other hand, there are two structural causes of homelessness for tāngata whaiora: housing unaffordability and unavailability. Housing issues are the key feature of structural causes of homelessness among and housing unaffordability is one of the obstacles that many face. Kate said some tāngata whaiora are unable to access housing due to the high price of housing. Nevertheless, two participants stated that there appears to be housing competition in urban Auckland due to a shortage of private housing, and population growth:

There is much competition among people wanting accommodation. So landlords 
are actually spoiled for choice. So, they can choose who they want. A lot of people with mental illness on benefits would be at their 'bottom of the list' because of being disrupted by their illness, they are unable to provide references. (Steven)

In addition to the individual and structural issues, participants identified two community causes of homelessness for tāngata whaiora. These are: estrangement from families / whānau, landlords, or flatmates and discrimination. Estrangement from families / whānau, landlords and/or flatmates is an important feature of community causes of homeless among tāngata whaiora as the community refuses to take them to their home or deny their rights to the property after admission into the service:

Admission into a unit may be the end of long process as far as landlords, neighbours, co-tenants, maybe concerned; the admission itself may be used as a means to evict you from the accommodation. (Eric)

They [tāngata whaiora] admitted onto the ward and family tell practitioners that they are unable to take the person back because they are struggling and they want somebody else to take it on. That's too much for them (Kate)

Discrimination by landlords is another main obstacle for tāngata whaiora in accessing housing. Due to a lack of information or misunderstanding about mental illness among the public, landlords perceive tāngata whaiora as non-ideal tenants. Therefore, landlords eliminate tāngata whaiora as possible tenants:

A lot of landlords advertising for rental, talking about wanting professionals or students to avoid unemployed and who are on benefits. (Steven)

The participants reported that this discrimination is caused by the media as it portrays alarmist and sensationalist views of how tāngata whaiora are dangerous to the public:

If you have not have any experience in mental illness in your family or community, then your only information is coming from the media. And if the media is telling you that these are dangerous people, they are all bad and not going to be good tenants for you. (Eric)

There are two major consequences of homelessness for tāngata whaiora, including multiple difficulties, and aggravation of mental illness. Kate identified that some of the multiple difficulties that tāngata whaiora face include accessing and maintaining income benefits; medication, and maintaining a daily routine. It is also difficult for tāngata whaiora to receive clinical support as they are required to provide their home address to receive assistance from support workers:

If you become homeless, where do you get your clinical support from? And where is your clinical monitoring? Where is your community support come from? You know where people try to help you to deal with your symptoms and the dayto-day community living issues that they are facing. (Eric)

Aggravation of illness is another consequence of being homeless for tāngata whaiora. Steven noted that some tāngata whaiora are re-admitted into hospital because "being homeless exacerbated their mental illness".

If you are prone to MI, and you become homeless, it is highly likely that the experience will tend to worsen your symptoms because you are suddenly in a position where you have no settled address, you have lost your address, you have lost your community and perhaps lost respect and self-image. (Eric) 


\section{Understanding of recovery concept and its relationship to 'home'}

Recovery as a process was the main definition of recovery for most participants. Two participants commented that they perceived recovery as a process because obtaining a home was a part of the process of tāngata whaiora`s recovery. Having a home was identified as a crucial factor of tāngata whaiora`s recovery as it provides a place for self-care and to manage their illness appropriately and securely:

Taking housing away [from tāngata whaiora] is like being in an Olympics [athlete] and cutting off somebody's ankle, isn't it? It kinds of not fair starting, you know, slightly tight in the starting block. (Kate)

\section{Policy and mental health practice implications}

All participants provided some mental health service development and practice suggestions to reduce homelessness among tāngata whaiora. Participants reported two practice suggestions: advocating for the housing needs for tāngata whaiora and providing a new categorisation of homelessness in mental health services. Two participants reported that advocacy for tāngata whaiora`s housing needs should be directed to both the public and the government. Steven said that it is necessary for social workers:

To advocate and educate the public to counter stigma about mental illness. They might need to have social workers running a housing advocacy service to support and lobby for affordable housing for mental health clients.

Alternatively, Eric offered a new classification of homelessness in mental health to quantify the number of homeless tāngata whaiora in mental health services in both non-governmental organisations and DHBs. This classification consisted of four groups: 1) people who have an established address which they can return to, 2) people who lose their accommodation immediately upon their admission, 3) people who lose their accommodations at some point during the admission to [services] and 4) rough sleepers at the point of admission who remain homeless when admitted. Eric explains an advantage of using this classification:

To indicate those clients [tāngata whaiora] who are going to have accommodation issues, prior to discharge and they get flagged very quickly in the admission process. So that, all the staff that will be involved with the client in an in-patient unit, or community [mental health] team can recognise that this is going to be an issue that will need to be addressed.

\section{Discussion}

It is apparent from the findings reported in this study that homelessness is indeed prevalent among urban Auckland's tāngata whaiora, and the cyclical nature of this problem presents a serious obstacle for their recovery. The findings also support themes that are reported in existing literature. The experiences reported by mental health social workers in this study recommend a review and reconceptualization of the official definition of homelessness/severe housing deprivation in Aotearoa, as the current definition fails to capture the systematic issues of iterative homelessness in mental health services, particularly for the at-risk homeless population. In this study, types of homelessness described by the participants were; rough sleepers, transients, and living in an inappropriate and/or insecure accommodation (Elgin, 2010; Richards, 2009). This iterative homelessness is the ongoing cycle of loss or movement from accommodation to hospitalisation in both the short and long-term as they remain tenuously housed and at continued risk of being rough sleepers (Robinson, 2003). 
Quantitative research into the nature and extent of this issue would help address the current invisibility of homelessness amongst tāngata whaiora in Auckland. It is recommended that a new categorisation of homelessness be implemented in order to identify and quantify a number of homeless tāngata whaiora in mental health services.

The debate over the definition and categorisation of homelessness in Aotearoa is one of the themes that emerged from the literature review (Amore et al., 2011; Richards, 2009). Participants in this study noted that tāngata whaiora are either transients or tenuously housed, and some return from the community to the hospital several times due to loss of accommodation. This finding was consistent with other studies (Elgin, 2010; Timms \& McLachlan, 2009). Nevertheless, the current news media and local government response to homelessness in Auckland is mainly focused on those people who are without shelter (Kang, 2016; Auckland Council, 2012). Amore et al. (2011) rightly argue that "definitions produced by government agencies with responsibility for addressing homelessness tend to minimise the population and concentrate on those who are publicly visible" (p. 20). Thus, official statistical categories should portray homelessness as it is perceived and defined by practitioners in order to address this current invisibility of homelessness amongst tāngata whaiora in Aotearoa.

The tension between individualist and structural approaches to the causes of homelessness was another theme which emerged from the literature (Leggatt-Cook \& Chamberlain, 2015) and was clearly identified from the data, demonstrating the growing recognition of the 'both/and' view of causes of homelessness.

When exploring the individual causes of homelessness, one of the themes discussed in the literature is whether homelessness is a lifestyle choice or personal failure (Leggatt-
Cook, 2007a; Leggatt-Cook, \& Chamberlain, 2015). In this study, all the participants stated that it is a myth that people choose to be homeless; rather, they become homeless as a result of choicelessness. This view is supported by other studies (Beaton, et al., 2015; Timms \& McLachlan, 2009). Hence, it would be completely inaccurate to assume that the majority of homeless tāngata whaiora choose to be homeless. The literature reported here demonstrates that there is a clear and intimate relationship between homelessness, housing difficulties and mental health (Peace et al., 2002; MHCA, 2009). In this study, the participants showed that there is an interconnected relationship between homelessness and mental health: they mutually reinforce each other but are also indirectly connected (MHCA, 2009).

The findings show that symptoms of mental illness along with a lack of skills to maintain housing are major individual causes of homelessness. Significantly, participants commented that the symptoms, rather than mental illness itself, were the main feature of individual causes of homelessness for tāngata whaiora. This suggests that the symptoms of mental illness may not be widely recognised in the urban Auckland community. Thus, it is recommended that social workers develop a collaborative multi-agency support forum where social housing providers, private landlords, mental health service teams and providers along with tāngata whaiora can meet and discuss any risks and protective factors with the aim of developing a tenancy management and support network for those at-risk homeless tāngata whaiora.

A structural view of homelessness (LeggattCook, 2007a) was also echoed in the data. When asked Why is homelessness prevalent among tāngata whaiora in the urban area of Auckland? all participants identified a shortage of affordable housing due to population growth and increased housing market competition and prices. This view is consistent with Leggatt-Cook's (2007b) 
study. Structural views of homelessness for tāngata whaiora must also take into account the implications of displacement of tāngata whenua from their turangawaewae as a result of European colonisation.

Interestingly, another theme emerged from the research, namely community causes of homelessness in mental health. In this study, participants identified several other community factors that lead to homelessness, including; rejection, estrangement and/or eviction from families/whānau members, landlords or flatmates. This finding may suggest that one of the contributors to homelessness is the inability to understand such behaviour among members of the community such as landlords or flatmates, thus risking the stability of tāngata whaiora's housing (O'Brien \& Leggatt-Cook, 2006). This may suggest that there is a need for mental health providers and practitioners to provide psycho-education to tāngata whaiora and their families/whānau regarding their symptoms of mental illness and wellness management strategies that may be introduced to reduce the likelihood of an estrangement from their families / whānau or eviction from landlords. It is also essential to promote that iwi and hapū are responsible to practice kaitiakitanga to atrisk homeless tāngata whaiora (Wellington City Council, 2014).

Educating the community about the symptoms of mental illness and housing needs for tāngata whaiora is urgently required. The findings from this small study suggest there may be widespread ignorance of mental health issues among the general public, which contributes to homelessness among tāngata whaiora. In this study, two participants identified that community cause of homelessness among tāngata whaiora are caused and perpetuated by alarmist and sensationalist views by the media. Exclusion from stable housing due to prejudice and discrimination is a crucial issue for tāngata whaiora as not only excludes them from the community (MHCA, 2009), but also violates their human rights to have adequate housing for their recovery (New Zealand Human Rights Commission, 2010). Hence, it is argued that mental health social workers need to ensure that housing is understood as a basic human right (Wellington City Council, 2014) for tāngata whaiora.

These findings also suggest that recovery is a process. The recovery model is variously perceived as process, outcome, or both (Ramon et al., 2007). There was no mention by participants of the 'both/and' view of recovery. This is consistent with MHFNZ's (2008) view, which describes recovery as a personal journey of achievement through life that tāngata whaiora choose to have regardless of the existence or non-existence of mental illness, rather than curing the illness itself. Participants commented that obtaining an appropriate and secure home for tāngata whaiora is a crucial part of the recovery process for them and plays a significant role in their recovery ( $\mathrm{O}^{\prime}$ Brien \& Leggatt-Cook, 2006).

\section{Conclusion}

The main goal of this article was to explore the perspectives of mental health social workers about homelessness amongst tāngata whaiora in urban Auckland. This small study found that the lives of tāngata whaiora are affected by iterative homelessness as it does not merely impede recovery but also produces multiple challenges, and aggravation of mental illness. In order to address iterative homelessness, social workers and service providers need to find new ways of forming effective partnerships in order to advocate for tāngata whaiora who have experienced homelessness. The inclusion of other social service agencies is critical to facilitating social change and empowering tāngata whaiora who are affected by social exclusion. Effective interagency casemanagement and coordination amongst mental health services and social, homeless, community and housing agencies is an essential aspect of holistic and accessible care for at-risk homeless tāngata whaiora (O’Brien \& Leggatt-Cook, 2006). 
An official definition of homelessness requires consideration of a process view of recovery as tāngata whaiora require ongoing clinical treatment after discharge from the hospital or community-based residential care services. Māori homelessness, a condition where indigenous people are displaced from kinship relationship, ancestral lands and indigenous knowledge (Groot, Hodgetts, Nikaro \& Leggatt-Cook, 2011) should also be incorporated in the official definition of homelessness in Aotearoa New Zealand for greater inclusion. It is essential for the social work profession to take an active voice in challenging the current official definition of homelessness and its discourse amongst the general public.

As has been shown here, mental illnessrelated stigma and discrimination remains a significant challenge for tāngata whaiora in Aotearoa. Those tāngata whaiora who are living with their families/whānau, landlords and/or flatmates with lack of understanding of symptoms of mental illness are vulnerable to exclusion from housing. It is recommended that policy-makers support agencies to promote and educate the public about symptoms of mental illness and its stigmatisation and discrimination and tāngata whaiora rights to have adequate housing in partnership with other organisations such as: the New Zealand Coalition to End Homelessness; the Auckland Community Housing Providers Network; the Auckland City Council; Like Minds, Like Mine; and the New Zealand Human Rights Commission. Organising a multi-agency public awareness campaign (Mental Health Commission, 2005), Taku Manawa/human rights workshops (Human Rights Commission, 2011) and/ or Mental Health First Aid training courses (Jorm \& Kitchener, 2011) are recommended to improve the public attitude and management of symptoms of mental illness and homelessness issue for tángata whaiora in Auckland.

Ultimately, government policy on assessing the extent and nature of the problem, and funding and support of agencies may assist in developing appropriate interventions that promote the health of individuals and their communities. Such an investment is likely to lead to reduced costs and burdens in mental health facilities, and human costs in tāngata whaiora.

\section{References}

Amore, K., Baker, M., \& Howden-Chapman, P. (2011). The ETHOS definition and classification of homelessness: An analysis. European Journal of Homelessness. 5(2), 19-36.

Amore, K., Viggers, H., Baker, M. G., \& Howden-Chapman, P. (2013). Severe housing deprivation: the problem and its measurement. (Official Statistics Research Series, 6) Wellington, New Zealand: Statistics New Zealand. Retrieved from http://www.statisphere.govt.nz/furtherresources-and-info/official-statistics-research/series/2013/ severe-housing-deprivation.aspx.

Auckland Council. (2012). Auckland Council Homelessness action plan 2012-2015. Retrieved from http://www. aucklandcouncil.govt.nz/EN/planspoliciesprojects/ plansstrategies/Councilstrategies/Documents/ homelessnessactionplan.pdf.

Browne, M. A. O., Wells, J. E., Scott, K. M. (2006). Te Rau Hinengaro: The New Zealand mental health survey. Wellington, New Zealand: Ministry of Health. Retrieved from http://www.spinz.org.nz/file/FAQs/PDFs/mentalhealth-survey.pdf

Chamberlain, C., \& MacKenzie, D. (1992). Understanding contemporary homelessness: Issues of definition and meaning. Australian Journal of Social Issues, 27(4). 274-297.

Chen, M. (2015). Superdiversity stocktake: Implications for business, government and New Zealand. Retrieved from http://www.superdiversity.org/pdf/Superdiversity_ Stocktake\%20-\%20Full\%20Document.pdf

Cheer, J. A. (2009). The meaning of social inclusion to people with enduring mental health problems. Unpublished Master of Arts in Nursing thesis, Massey University. Auckland, New Zealand. Retrieved from http://mro.massey.ac.nz/ xmlui/bitstream/handle/10179/1239/02whole.pdf?sequence= 1 \&isAllowed=y

Christian, J. (2003). Introduction: Homelessness: Integrating international perspectives. Journal of Community and Applied Social Psychology. 13, 85-90. doi:10.1002/ casp.713

Colwell, A. (2009). Barriers to affordable housing for mental health service users. Unpublished Master of Public Policy thesis, Massey University, Auckland, New Zealand. Retrieved from http://mro.massey.ac.nz/bitstream/handle/ 10179/1153/02whole.pdf?sequence=1

Elgin, J. (2010). The impact of neighbourhood characteristics and support on well-being, housing satisfaction, and residential stability for people with mental illness. (Master's thesis, University of Canterbury, Christchurch, New Zealand). Retrieved from http://ir.canterbury. ac.nz/bitstream/handle/10092/5658/thesis_fulltext. pdf? sequence $=1$ \&isAllowed $=y$

Gawith, L., \& Abrams, P. (2006). Long journey to recovery for kiwi consumers: Recent developments in mental 
health policy and practice in New Zealand. Australian Psychologist, 41, 140-148. doi: 10.1080/00050060600657988

Groot, S., Hodgetts, D., Nikora, L., \& Leggat-Cook, C. (2011). A Māori homeless woman. Ethnography. 12(3), 375-397. doi: $10.1177 / 1466138110393794$

Harris, R. T. (2015). Invisible in the Super City: hidden homelessness in Auckland. Auckland, New Zealand: The Salvation Army Social Policy and Parliamentary Unit. Retrieved from http://www.salvationarmy.org.nz/ sites/default/files/uploads/20151118SPPUInvisible\% 20in\%20SuperCity\%20Web\%20PDF.pdf

Human Rights Commission. (2010). Human rights in New Zealand: Ngä Tika Tangata O Aotearoa. Wellington, New Zealand: Human Rights Commission. Retrieved from https://www.hrc.co.nz/files/7014/2388/0544/ Human_Rights_Review_2010_Full.pdf

Human Rights Commission. (2011). Taku Manawa: Building Human Rights Communities. Wellington, New Zealand: Human rights commission. Retrieved from https://www. hrc.co.nz/files/4714/2421/9547/Taku-Manawa-BuildingHuman-Rights-Communities.pdf

Jorm, A. F., \& Kitchener, B. A. (2011). Nothing a landmark achievement: Mental health first aid training reaches $1 \%$ of Australian adults. Australian and New Zealand Journal of Psychiatry, 45, 808-813. doi:10.3109/00048674.201 1.594785

Kang, S. (2016, June 17). Park up for Homes: Hundreds spend night in cars in support of homeless families. NZ Herald. Retrieved from http://www.nzherald.co.nz/nz/ news/article.cfm?c_id=1\&objectid=11657982.

Kell, S. \& Peace, R. (2002). Mental health and independent housing needs part 3: affordable, suitable, sustainable housing: a literature review. Wellington, New Zealand: Ministry of Social Development. Retrieved from https://www.msd.govt.nz/documents/about-msd-andour-work/publications-resources/research/mentalhealth-independent-housing-needs/mental-health-andindependent-housing-needs-part-3.pdf.

Laurenson, P., \& Collins, D. (2006). Towards inclusion: Local government, public space and homelessness in New Zealand. New Zealand Geographer, 62. 185-195 doi:10.1111/j.1745-7939.2006.00069.x

Leggatt-Cook, C. (2007a). Homelessness in New Zealand: A discussion and synthesis of research findings. Auckland, New Zealand: Methodist Ministry Northern.

Leggatt-Cook, C. (2007b). Housing demand, supply and affordability in the Auckland region: A review of current trends and drivers. Auckland, New Zealand, Auckland Regional Council. Retrieved from http://www. knowledgeauckland.org.nz/assets/publications/Housing_ demand_supply_and_affordability_in_the_Auckland_ region_A_review_of_current_trends_and_drivers_ Background_report.pdf.

Leggatt-Cook, C., \& Chamberlain, K. (2015). Houses with elastic walls: Negotiating home and homelessness within the policy domain. Kōtuitui: New Zealand Journal of Social Sciences Online 10(1), 10-22, doi:10.1080/ 1177083X.2014.927370.

Mental Health Council of Australia (2009). Home truths: Mental health, housing and homelessness in Australia. Canberra, ACT, Australia: Author Accessed at https://mhaustralia.org/publication/home-truths-mentalhealth-housing-and-homelessness-australia-2009.
Mental Health Foundation of New Zealand. (2008). Destination: recovery. Auckland, New Zealand: Author.

Mental Health Foundation of New Zealand. (2014). Mental Health Foundation: Quick facts and stats 2014. Retrieved from http://www.mentalhealth.org.nz/assets/ Uploads/MHF-Quick-facts-and-stats-FINAL.pdf.

Mental Health Commission. (2005). Reducing discrimination against people with mental illness Te Hekenga: Whakamana i te Tangata Whaiora Multi-agency plan 2005 - 2007. Wellington, New Zealand: Mental Health Commission. Retrieved from http://www.hdc. org.nz/media/199626/reducing\%20discrimination\%20 against\%20people\%20with\%20mental\%20illness\%20 \%20multi\%20agency\%20plan\%202005-2007.pdf.

Mental Health Commission. (2012). Blueprint II Improving mental health and wellbeing for all New Zealanders: How things need to be. Wellington, New Zealand: Mental Health Commission. Retrieved from http://www.hdc.org. nz/media/207642/blueprint\%20ii\%20how\%20things\%20 need\%20to\%20be.pdf.

Morrell-Bellai, T., Goering, P. N., \& Boydell, K. M. (2000). Becoming and remaining homeless: A qualitative investigation. Issues in Mental Health Nursing, 21, 581 - 604. doi: 10.1080/01612840050110290.

National Coalition for the Homeless. (2009). Mental illness and homeless. Retrieved June, 12, 2011 from http:// www.nationalhomeless.org/factsheets/Mental_IIIness.html.

New Zealand Human Rights Commission. (2010). Human rights in New Zealand: Ngä Tika Tangata O Aotearoa. Wellington, New Zealand: Author.

O`Brien, M., \& Leggatt-Cook, C. (2006). Accommodation needs and preferences of tangata whai ora/consumers of mental health services in Northland. Auckland, New Zealand: Northern Disability Support Agency. Retrieved from http://www.networknorth.org.nz/file/ housing/research_northland_reportfinal_25_april.pdf.

Peace, R., Kell, S., Pere, L., Marshall, K., \& Ballantyne, S. (2002). Mental health and independent housing needs part 1: A summary of the research. Wellington, New Zealand: Ministry of Social Development. Retrieved from https://www.msd.govt.nz/documents/about-msdand-our-work/publications-resources/research/mentalhealth-independent-housing-needs/mental-health-andindependent-housing-needs-part-1.pdf.

Parliamentary Library. (2014). Retrieved April 20, 2015 from http://www.parliament.nz/resource/ennz/00PLEcoRP14021/ e5be279de0819fd2d7a9f53e0cf4ff50b5f30aa0.

Piat, M., Sabetti, J., \& Couture, A. (2009). What does recovery mean for me? Perspective of Canadian mental health consumers. Psychiatric Rehabilitation Journal, 32(3), 199-207. doi:10.2975/32.3.2009.199.207.

Ramon, S., Healy, B., \& Renouf, N. (2007). Recovery from mental illness as an emergent concept and practice in Australia and the UK. International Journal of Social Psychiatry, 53(108), 108-122. doi:10.1177/0020764006075018.

Richard, S. (2009). Homelessness in Aotearoa: Issues and recommendations: Report for the New Zealand Coalition to End Homelessness. Wellington, New Zealand: Regional Public Health. Retrieved from http://nzceh.org. nz/about/Publications/homelessness_in_aotearoa.pdf.

Robinson, C. (2003). Understanding iterative homelessness: The case of people with mental disorders. Melbourne, Australia: Australian Housing and Urban Research 


\section{ORIGINAL ARTICLE}

QUALITATIVE RESEARCH

Institute. Retrieved from https://www.ahuri.edu.au/ data/assets/pdf_file/0014/2219/AHURI_Final_Report_ No45_Understanding_iterative_homelessness_the_ case_of_people_with_mental_disorders.pdf.

Statistics New Zealand. (2009). New Zealand definition of homelessness. Wellington, New Zealand: Statistics New Zealand. Retrieved from http://www.aucklandcitymission. org.nz/uploads/file/Homelessness-definition-July09\% 5B1\%5D.pdf.

Statistics New Zealand. (2014). New Zealand definition of homelessness: update. Wellington, New Zealand, Statistics New Zealand. Retrieved from http://www. stats.govt.nz/ /media/Statistics/browse-categories/ people-and-communities/housing/homelessness-defnupdate-2015/nz-definition-homelessness-update.pdf.

Timms, P., \& McLachlan, A. (2009). Mental health on the margins: Homelessness and mental disorder in T. Davies \& T. Craig (Eds.), $A B C$ of mental health. ( ${ }^{\text {nd }}$ ed., pp.86-90). Oxford, England: Wiley-Blackwell Publishing.

Wellington City Council. (2014). Te Mahana: Ending homelessness in Wellington- A strategy for 2014-2020. Retrieved from http://wellington.govt.nz/ /media/yourcouncil/plans-policies-and-bylaws/plans-and-policies/ato-z/homelessness/files/2014-temahana-strategy.pdf?la=en. 